


\title{
Effects of Neem (Azadirachta indica) and Pumpkin (Cucurbita maxima) Seeds and their Combination as Feed Additive on Intake, Muscle chemical composi- tion, Sensory Quality and Hematology of Broilers
}

\author{
Meseret Girma ${ }^{1}$, Negassi Ameha ${ }^{1}$, Tesfaheywet Zeryehun ${ }^{2}, Z_{\text {inabu Mathewos }}{ }^{1}$ and \\ Netsanet Tadesse ${ }^{2}$ \\ ${ }^{1}$ School of Animal and Range Sciences, Haramaya University, PO Box 138, Dire Dawa, Ethiopia \\ ${ }^{2}$ College of Veterinary Medicine, Haramaya University, PO Box 138, Dire Dawa, Ethiopia \\ ${ }^{*}$ Corresponding author: Dr. Meseret Girma; E-mail: meseretgirma4@gmail.com
}

\begin{abstract}
A study was conducted to evaluate the efficacy of feeding neem (Azadirachta indica) and pumpkin (Cucurbita maxima) seed as natural feed additive for broiler chicks on dry matter intake, mortality, meat quality and blood parameters of broilers. One hundred ninety two day-old Cobb 500 chicks distributed to four treatments with three replications in a completely randomized design. Feed offered and refusals were recorded and Dry matter intake was calculated as the difference between the two on dry matter basis. At the end of the trial, four broilers were randomly picked up from each replication and slaughtered for carcass evaluation and the treatment used were ration that contain only commercial broiler diet (0 kg Neem and pumpkin seed (0NS-PS)), $1 \mathrm{~kg}$ neem seed on $100 \mathrm{~kg}$ commercial broiler diet (1NS), $1 \mathrm{~kg}$ pumpkin seed on $100 \mathrm{~kg}$ commercial broiler diet (1PS) and $1 \mathrm{~kg}$ of neem and pumpkin seed combination on $100 \mathrm{~kg}$ of commercial broiler diet (1NS-PS) stands for Treatment1, Treatment 2 , Treatment 3 and Treatment 4 respectively. The average daily dry matter intake during the entire experimental period was 106, 111, 114 and $117 \mathrm{~g} /$ bird for 0NS-PS, 1NS, 1PS and 1NS-PS respectively, and it was significantly higher $(p<0.05)$ for 1 NS-PS as compared to 0NS-PS, 1 NS and 1PS. The serum cholesterol and white blood cell of broilers in the experimental period were significantly $(p<0.05)$ decreased but total blood protein was significantly ( $p<$ 0.05) increased among treatment. Crude protein content of breast and thigh meat was significantly high for 1NS-PS. It is concluded that neem and pumpkin seed can be a good feed additive for broiler production aside its nutritional importance.
\end{abstract}

Key words: Broiler; Feed additive; Hematology; Neem and Pumpkin seed. 


\section{Introduction}

Chicken meat and eggs have been recommended to bridge the protein gap more than other species of livestock because of short generation interval, high rate of productivity, quick turnover rate, higher feed efficiency, small land requirement and relatively low capital investment (Ani and Okeke, 2011).

Feed additives are plant-derived products incorporated into diets to improve the productivity of livestock through improvement of feed properties, promotion of the animals' production performance, and improving the quality of food derived from those animals (Windisch et al., 2008). The objective of feed additives is maintaining greater livability and lowered mortality in poultry chickens. These feed additives are termed as growth promoters and also stimulate feed intake (Ihsan, 2017). Modern intensive poultry production has achieved great gains in the production of high-quality safe chicken meat and eggs. Biologically active constituents of herbs possess many beneficial properties. Many synthetic drugs and growth promoters are supplemented to broilers to effect rapid growth, but their use have shown many disadvantages like high cost and adverse side effect on health of broilers and human, human becoming resistant to the antibiotic and residual effect. There are a number of non-therapeutic alternatives such as enzymes, inorganic acids, probiotics, prebiotics and herbs (Banerjee, 2006). The use of medicinal plants is gradually gaining importance as natural products have a medicinal value against various diseases and have no residue in tissues and eggs. One of the plants is Azadirachta indica, commonly known as "Neem", and contains various active substances such as azadiractin, nimbin, nimbindin, quercetin and others which have antioxidant, antibacterial, antifungal, anthelmintic and antiprotozoal properties beside immuno-stimulatory effects the finding of Jawad et al. (2013); Ahsan et al. (1999) observed that the beneficial influence of neem leaves on antigen in broiler chickens.

Similarly, pumpkin (Cucurbita maxima) seed is one of the alternatives that have the potential to serve as protein source in the poultry industry because of its high crude protein content (Wafar et al., 2017). Besides its use as hypoglycemia agent pumpkin seed applications use for the treatment of parasites and hypercholesterolemia (Kerise et al., 2008). The pumpkin seed contains a substance called cucurbitin that treats worms and parasites (Bauri et al., 2015; Acorda et al., 2019). However, there is no information available about the integral utilization (combined effect) of Neem (Azadirachta indica) and pumpkin 
(Cucurbita maxima) seed combination in broiler feeding. Therefore, the current experiment was conducted to evaluate the effect of feeding neem (Azadirachta indica) and pumpkin (Cucurbita maxima) seed as natural feed additive on intake, meat sensory characteristics, hematology and serum biochemical aspects of broilers.

\section{Materials and methods}

\section{Experimental site}

The experiment was conducted in Poultry Farm at Haramaya University, which is located at $42^{\circ} 3^{\prime}$ east longitude, $9^{\circ} 26^{\prime}$ 'north latitude, at an altitude of 1980 meter above sea level and $515 \mathrm{~km}$ east of Addis Ababa, the capital city of Ethiopia. The mean annual rainfall of the area amounts to $780 \mathrm{~mm}$ and the average minimum and maximum temperatures are $8.5^{\circ} \mathrm{C}$ and $23.4^{\circ} \mathrm{C}$, respectively (Mishra et al., 2004).

\section{Feed additives and rations}

The starter and finisher commercial broiler diets were purchased from Debre Zeit Alema Koudijs farm. Dietary ingredients used for this study were maize grain, wheat short, soybean meal, Noug seed cake, salt, vitamin premix, limestone and dicalcium phosphate. Dried neem seed was collected from Dire Dawa town and pumpkin seed was purchased from Harar. The Dried neem and pumpkin seed were ground in the size of adjusted hammer mill at $5 \mathrm{~mm}$ by at Haramaya University feed processing plant. The obtained powder was used as feed additive in the broiler ration. The starter phase was until 3 weeks of age. The finisher phase was offered from 3 weeks up to slaughtering (42 days).

\section{Experimental design and treatments}

Completely Randomized Design (CRD) with four treatments and three replications were used in the study. One hundred ninety two day-old chicks were randomly allotted in to four treatments. The treatments were only commercial broiler diet without neem seed powder and pumpkin seed powder (control), $1 \mathrm{~kg}$ of neem seed powder on $100 \mathrm{~kg}$ commercial broiler diet, $1 \mathrm{~kg}$ of pumpkin seed powder on $100 \mathrm{~kg}$ commercial broiler diet and $1 \mathrm{~kg}$ of neem seed powder and pumpkin seed powder combination on $100 \mathrm{~kg}$ commercial broiler diet which were termed as 0NS-PS, 1NS, 1PS and 1NS-PS, respectively. 


\section{Experimental chicken management}

The experimental houses were cleaned and disinfected two weeks before of the arrival of the chicks. The pens were washed with water and detergent then disinfected by HI-7(1L/330L water) and the chicks were kept on floor covered with wood shaving litter material of about $6.5 \mathrm{~cm}$ depth. The feeding and drinking troughs were properly cleaned, dried and disinfected before chicks' arrival. Experimental chicks (Cobb500) were purchased from Debre Zeit Alema Koudijs farm. Each pen was also equipped with a 250 -watt infrared heat bulb. The chicks were fed ad libitum in groups in feeder throughout the experimental period. The neem and pumpkin seed powder added at rate of $1 \mathrm{~kg} / 100 \mathrm{~kg}$ diet alone and their combination of $0.5 \mathrm{~kg} / 100 \mathrm{~kg}$ each added to diet for treatment. Water was available at all times, and provided in plastic fountains, as well as the watering troughs. The experiment was conducted for a total of 42 days. The chicks were vaccinated against Newcastle Disease on day 7 (HB1) by ocular route and on day 21 (Lasota) was given through by drinking water. The study animals were also vaccinated for Gumboro on day 14 and 28 through drinking water. Other health precautions and disease control measures were taken throughout the study period. Vitamins were given to chicks through drinking water to recover from stress of transportation and early age acclimatization problems according to the manufacturer's recommendation.

\section{Measurements}

\section{Dry matter intake}

The amount of feed offered and refused per pen was recorded daily. The amount of feed consumed was determined as the difference between the feed offered and refused on DM basis.

\section{Chick mortality}

Daily monitoring of the chickens was followed as a routine activity to check the health status and to record deaths. Mortality was recorded as it occurred and was determined for each treatment as a percentage of the total mortality at the end of the whole experiment. Calculation of mortality percentage /MP/ is expressed as percentage as follows:

$$
\text { Mortality percentage(MP) }=\frac{\text { Number of dead chicks }}{\text { Number of total chicks }} * 100
$$




\section{Hematological and serum biochemical parameters}

Blood samples were collected at slaughter randomly from the jugular vein of 4 chicks (5 ml) from each replicate A sample of $2.5 \mathrm{ml}$ of blood was drawn into EDTA (ethylene diamine tetraacetic acid) tube in order to prevent coagulation while the remaining $2.5 \mathrm{ml}$ was drawn in plain tube and left to coagulate. $\mathrm{RBC}$ and WBC were determined by manual methods by using improved neubauerhemocytometer chamber (Bernard et al., 2000). Hemoglobin concentration was determined by using acid hematin or Sahli's methods. The packed cell volume (PCV) was determined by microhematocrit method after the blood in EDTA was centrifuged at $3000 \mathrm{rpm}$ for 5 minutes. Finally, Serum was harvested from blood collected in plain tube to Endorphin tube and stored at $-20^{\circ} \mathrm{C}$ and analyzed for serum chemistry parameters with an automated chemistry analyzer (Doumas et al., 1981).

\section{Chemical composition of meat}

Chemical composition of the meat samples was analyzed following the procedure (AOAC, 1995). Samples of breast and thigh muscles were minced, dried and ground with $1 \mathrm{~mm}$ size by mechanical miller then analyzed for the content of dry matter, crude protein, ether extract and ash. Dry matter was determined by drying $6 \mathrm{~g}$ of ground meat samples in a draft oven at $105^{\circ} \mathrm{C}$ for 24 hrs. Nitrogen $(\mathrm{N})$ was determined according to Kjeldahl procedure and crude protein content of the sample was calculated as $\mathrm{N}^{*} 6.25$ (AOAC, 1995). Total lipid (ether extract) content of the muscles determined following the standard procedure (AOAC, 1995). Total mineral content was determined by burning 6 $\mathrm{g}$ of the samples in a muffle furnace at $550^{\circ} \mathrm{C}$ for 3 hours.

\section{Sensory evaluation of meat}

The sensory parameters determined were juiciness, tenderness, flavor and overall acceptance. Skinless breast and thigh muscle samples were frozen until cooking, the pieces were thawed at room temperature minced and cut into $2.5 \mathrm{~cm}$ cubes by using knife. Breast meat was cooked for $15 \mathrm{~min}$ on a pan by vegetable oil, but without salt. Thigh cooking required 2 min more than the breast. After cooking, the pieces were cooled to room temperature. The breast and thigh meats were evaluated following the sensory profile procedure (ISO, 2003). The panel consist 20 trained graduating classes of undergraduate and postgraduate students of Food Science Department of Haramaya University. Panelists were instructed to chew and taste the meat, drink water and rinse 
their mouth with bottled drinking water of room temperature between each sample and pause for 20 seconds before tasting the next sample.

\section{Statistical analysis}

The experimental data were subjected to analysis of variance (ANOVA) using the General Linear Model (GLM) procedure of SAS (2002) version 9.2. When the analysis of variance revealed the existence of significant differences, differences among treatment means were compared using least significant difference (LSD) test.

The model used for data analysis is;

Yij $=\mu+\mathrm{Ti}+$ eij

Where:

Yij = the response variable (is an observation (experimental unit), $\mu=$ Over all mean

$\mathrm{Ti}=$ Treatments effect

eij $=$ Random error term

\section{Results}

\section{Dry matter intake}

The average daily and total dry matter intake (DMI) during the starter and finisher phases as well as for the whole experimental period was significantly affected $(\mathrm{P}<0.05)$ by treatment (Table 1$)$. Accordingly, addition of neem seed, pumpkin seed and their combination to the diet has improved DMI as compared to the control during the entire period. DMI increased with addition of neem seed and pumpkin seed alone and their combination. 
Table 1. Effect of feeding neem and pumpkin seed powder and their combination on dry matter intake of broilers

\begin{tabular}{|c|c|c|c|c|c|c|}
\hline \multirow[t]{2}{*}{ Parameter } & \multicolumn{4}{|c|}{ Treatments } & \multirow[b]{2}{*}{ SEM } & \multirow[b]{2}{*}{$p$-value } \\
\hline & ONS-PS & $1 \mathrm{NS}$ & 1PS & 1NS-PS & & \\
\hline \multicolumn{7}{|l|}{ Starter phase } \\
\hline Total DMI (g) & $1022^{\mathrm{a}}$ & $944^{\mathrm{b}}$ & $1009^{\mathrm{a}}$ & $1033^{\mathrm{a}}$ & 12.4 & 0.013 \\
\hline Daily DMI (g/bird/day) & $49^{\mathrm{a}}$ & $44^{\mathrm{b}}$ & $48^{\mathrm{a}}$ & $49^{\mathrm{a}}$ & 0.59 & 0.013 \\
\hline \multicolumn{7}{|l|}{ Finisher phase } \\
\hline Total DMI (g) & $3323^{\mathrm{b}}$ & $3505^{\mathrm{a}}$ & $3669^{\mathrm{a}}$ & $3729^{\mathrm{a}}$ & 54.6 & 0.007 \\
\hline Daily DMI (g/bird/day) & $166^{\mathrm{b}}$ & $179^{\mathrm{a}}$ & $183^{\mathrm{a}}$ & $186^{\mathrm{a}}$ & 2.73 & 0.007 \\
\hline \multicolumn{7}{|l|}{ Entire period } \\
\hline Total DMI (g) & $4394^{\mathrm{c}}$ & $4565^{\mathrm{b}}$ & $4701^{\mathrm{ab}}$ & $4810^{\mathrm{a}}$ & 56.6 & 0.015 \\
\hline Daily DMI (g/bird/day) & $106^{c}$ & $111^{\mathrm{b}}$ & $114^{\mathrm{ab}}$ & $117^{\mathrm{a}}$ & 1.38 & 0.015 \\
\hline
\end{tabular}

\section{Hematological and serum biochemical parameters}

Results in Table 2 refer to presence of significant differences $(\mathrm{P}<0.05)$ between the control group and experimental group in total protein (TP) and serum cholesterol concentration. Total protein recorded was $3.46 \mathrm{~g} / \mathrm{dl}$ in 0NS-PS compared with $1 \mathrm{NS}, 1 \mathrm{PS}$ and $1 \mathrm{NS}-\mathrm{PS}$ which was $4.24,4.4$ and $5.1 \mathrm{~g} / \mathrm{dl}$, respectively.

Table 2. Effect of adding neem seed powder, pumpkin seed powder and their combination on some hematological indicators and serum biochemistry of broiler chicks

\begin{tabular}{lcccccc}
\hline Parameters & Treatments \\
\cline { 2 - 7 } & 0NS-PS & 1NS & 1PS & 1NS-PS & SEM & $\boldsymbol{p}$-value \\
\hline Packed cell volume (\%) & 33.68 & 38.98 & 36.75 & 38.04 & 1.096 & 0.3847 \\
Red blood cell (x10 $/ \mathrm{mm})$ & 3.633 & 4.033 & 3.55 & 3.70 & 0.093 & 0.2993 \\
White blood cell (x10/mm) & $66.08^{\mathrm{a}}$ & $63.27^{\mathrm{b}}$ & $62.1^{\mathrm{bc}}$ & $59.34^{\mathrm{c}}$ & 0.875 & 0.0032 \\
Hemoglobin $(\mathrm{g} / \mathrm{dl})$ & 11.35 & 12.27 & 10.77 & 11.30 & 0.293 & 0.3761 \\
Serum cholesterol $(\mathrm{mg} / \mathrm{dl})$ & $106.54^{\mathrm{a}}$ & $95.50^{\mathrm{b}}$ & $87.46^{\mathrm{c}}$ & $85.25^{\mathrm{c}}$ & 2.668 & 0.0004 \\
Total blood protein $(\mathrm{g} / \mathrm{dl})$ & $3.458^{\mathrm{c}}$ & $4.235^{\mathrm{b}}$ & $4.40^{\mathrm{b}}$ & $5.10^{\mathrm{a}}$ & 0.188 & 0.0005 \\
\hline abc Means within a row with different superscript letters are significantly different; $(P<0.05) ;$ SEM=Standard \\
error of the mean.
\end{tabular}




\section{Chick mortality percentage}

The results showed that the mortality rate of the broilers (Table 3) was statistically not significant $(p>0.05)$.

Table 3. Effect of adding the neem seed powder, pumpkin seed powder and their combination on mortality percentage of broilers

\begin{tabular}{lcccccc}
\hline Parameters (\%) & \multicolumn{2}{c}{ Treatments } & & & & \\
\cline { 2 - 7 } & 0NS-PS & NS & PS & INS-PS & SEM & $p$-value \\
\hline Mortality starter phase & 6.25 & 2.08 & 2.08 & 4.16 & 0.93 & 0.3630 \\
Mortality finisher phase & 4.44 & 4.30 & 2.08 & 4.30 & 0.96 & 0.8399 \\
Mortality entire period & 10.42 & 6.25 & 4.16 & 8.33 & 1.29 & 0.3999 \\
\hline
\end{tabular}

$\overline{{ }^{a b c} \text { Means within a row with different superscript letters are significantly different; }(P<0.05) ; S E M=\text { Standard }}$ error of the mean.

\section{Sensory evaluation of meat}

The panel members did not find differences in the sensorial quality of the breast and the thigh meat (Table 4), which proves that the neem seed powder and pumpkin seed powder alone and their combination did not significantly $(p>0.05)$ affect the juiciness, tenderness, flavor, and overall acceptance of the meat from the breast and thigh of broiler chicken.

Table 4. Score of the effect of adding neem seed powder, pumpkin seed powder and their combination on meat sensory characteristics of broilers

\begin{tabular}{|c|c|c|c|c|c|c|}
\hline \multirow{2}{*}{$\begin{array}{l}\text { Parameters } \\
\text { Juiciness }\end{array}$} & \multicolumn{6}{|c|}{ Treatments } \\
\hline & 0NS-PS & $1 \mathrm{NS}$ & 1PS & 1NS-PS & SEM & $p$-value \\
\hline Breast & 3.90 & 3.90 & 3.90 & 3.70 & 0.036 & 0.0951 \\
\hline Thigh & 3.50 & 3.80 & 3.65 & 3.65 & 0.043 & 0.0799 \\
\hline \multicolumn{7}{|l|}{ Tenderness } \\
\hline Breast & 3.75 & 3.65 & 3.75 & 3.85 & 0.030 & 0.1189 \\
\hline Thigh & 3.55 & 3.65 & 3.75 & 3.53 & 0.038 & 0.1457 \\
\hline \multicolumn{7}{|l|}{ Flavor } \\
\hline Breast & 3.65 & 3.80 & 3.70 & 3.85 & 0.054 & 0.6075 \\
\hline Thigh & 3.80 & 3.70 & 3.60 & 3.90 & 0.051 & 0.1927 \\
\hline \multicolumn{7}{|c|}{ Overall acceptance } \\
\hline Breast & 3.70 & 3.90 & 3.70 & 3.70 & 0.034 & 0.0519 \\
\hline Thigh & 3.45 & 3.75 & 3.80 & 3.75 & 0.058 & 0.1043 \\
\hline \multicolumn{7}{|c|}{$\begin{array}{l}\overline{a b} \text { Means within a row with different superscript letters are significantly different; }(P<0.05) ; S E M=S t a n d a r d ~ e r- \\
\text { ror of the mean. Sensory scale }=\text { Five-point sensory scale for juiciness, flavor, tenderness and overall acceptance; } \\
\text { Juiciness }(5=\text { very juicy, } 4=\text { juicy, } 3=\text { moderately juicy, } 2=d r y \text { and } 1=\text { very dry }) ; \text { Tenderness }(5=\text { very tender, } \\
4=\text { tender, } 3=\text { moderately tender, } 2=\text { tough and } 1=\text { very tough }) ; \text { Flavor }(5=\text { excellent, } 4=\text { good, } 3=\text { accepted, } \\
2=\text { poor and } 1=\text { extremely poor }) ; \text { Overall acceptance }(5=\text { excellent, } 4=\text { good, } 3=\text { accepted, } 2=\text { poor and } 1= \\
\text { extremely poor }) \text {. }\end{array}$} \\
\hline
\end{tabular}




\section{Chemical composition of meat}

The proximate chemical composition of breast and thigh meat of broiler was indicated on Table 5. In this study, 1NS-PS was higher in CP\% compared with control and other treatments groups.

Table 5. Effect of adding neem seed powder, pumpkin seed powder and their combination on meat chemical composition of broilers

\begin{tabular}{|c|c|c|c|c|c|c|}
\hline \multirow[t]{2}{*}{ Parameters (\%) } & \multicolumn{4}{|c|}{ Treatments } & \multirow[b]{2}{*}{ SEM } & \multirow[b]{2}{*}{$p$-value } \\
\hline & 0NS-PS & $1 \mathrm{NS}$ & 1PS & 1NS-PS & & \\
\hline \multicolumn{7}{|l|}{ Moisture } \\
\hline Breast & 75.51 & 75.52 & 75.59 & 75.64 & 0.021 & 0.0682 \\
\hline Thigh & 73.66 & 73.75 & 73.70 & 73.74 & 0.022 & 0.4717 \\
\hline \multicolumn{7}{|l|}{ Crude protein } \\
\hline Breast & $21.63^{\mathrm{d}}$ & $27.32^{\mathrm{c}}$ & $28.06^{\mathrm{b}}$ & $29.66^{\mathrm{a}}$ & 0.914 & $<.0001$ \\
\hline Thigh & $20.52^{\mathrm{d}}$ & $23.32^{\mathrm{c}}$ & $23.37^{\mathrm{b}}$ & $24.08^{\mathrm{a}}$ & 0.411 & $<.0001$ \\
\hline \multicolumn{7}{|l|}{ Ether extract } \\
\hline Breast & 6.85 & 6.78 & 6.83 & 7.18 & 0.117 & 0.6715 \\
\hline Thigh & 8.29 & 8.48 & 7.92 & 8.66 & 0.109 & 0.0641 \\
\hline \multicolumn{7}{|l|}{ Ash } \\
\hline Breast & 4.88 & 5.05 & 5.09 & 4.95 & 0.043 & 0.3564 \\
\hline Thigh & 3.78 & 3.88 & 3.79 & 4.09 & 0.063 & 0.3063 \\
\hline
\end{tabular}

\section{Discussion}

Lower dry matter intake during starter period at inclusion level 1NS than other treatments this may be chickens doesn't adapt to additive at early phase. Whereas, dry matter intake during finisher and entire experiment period were higher in 1NS-PS as compare to control and 1NS. The study of Ogbuemu et al. (2011) who reported that neem seed has natural substances that stimulate the appetite for feed intake. Pumpkin seed is used to stimulate animal digestive system by enhance the production of digestive enzymes and improve utilization of digested nutrients through enhanced liver functions (Ihsan, 2017). The effect addition of aromatic plants and their extracts on feeds and drinking water has positive effect on feed intake, feed conversion ratio, growth performance and carcass yield (Alcicek et al., 2003). 
The result obtained for 1NS-PS was superior to other treatments on DMI, total blood protein and crude protein content of breast as well as thigh muscle. Ihsan (2017) also reported that addition of neem powder in broiler diets significantly higher total protein value. Significantly $(p<0.05)$ lower serum cholesterol concentration was recorded in 1PS and 1NS-PS compared with 0NS-PS and $1 \mathrm{NS}$. The reason for the reduction was polyunsaturated fat in pumpkin seed specifically omega-3 and omega-6 fatty acids (Sirelkhatim and Asha, 2014). Similar research has shown that these essential fatty acids can lower bad cholesterol and prevent cardiovascular disease. Pumpkin seed has been reported to possess cholesterol lowering effect and these results are in agreement with the observations of previous researchers (Meineri et al., 2018; Fruhwirth and Hermetter, 2007). This is similar with the finding of Perez-Gutierrez (2016) who reported that Glycemia and cholesterol levels were significantly $(p<0.05)$ lower in the serum of chicken fed pumpkin seed supplemented diets than in those fed diet without pumpkin seed supplementation. Similarly, the study of Ihsan (2017) who reported that low cholesterol concentration in treatment diet with neem than without neem. The current study result was similar to finding of Bonsu et al. (2012) who reported that inclusion of $1 \%$ neem leaf meal lower the number of WBC when compared with the control.

The higher $\mathrm{WBC}$ in the control indicates a probable higher resistance which might have stimulated the production of WBC to fight against the potential causative agent. The relatively lower WBC of the chicken fed the neem seed could be attributed to no fight against potential disease threats before the body's system could be stimulated to produce WBC. This is in agreement with the findings of Fajinmi et al. (1990) who reported that neem seeds are valuable materials and not inimical to human and livestock health. The values obtained for all hematological parameters were within the normal range (Douglas et al., 2010).

Mortality in this study was not severe because pumpkin seed addition decreases mortality; this can be related to pumpkins' vitamin C content as a natural antioxidant and a reducer of heat stress. Furthermore, pumpkin has been considered beneficial to health because it contains various biologically active components such as polysaccharides, p-amino benzoic acid, fixed oils, sterols, proteins and peptides (Yadav et al., 2010). Several in vitro studies reported significant antibacterial and antifungal properties of pumpkin seed oil (Xiong, 2000; Ng et al., 2002). The current finding agreed with the study result of Imran et al. (2014) who reported addition of $1 \%$ neem seed cake on the feed of 
broiler which lower mortality and parasitic count. The present findings showed that addition of neem seed powder and pumpkin seed powder may even have some medicinal, nutritional and health benefit and they can be used as a feed ingredient in broiler production without compromising the hematological parameters, carcass characteristics and meat taste at the present addition rate. This may be due to the synergetic effect of the bioactive compounds in herbal seed which have beneficial effect on performance (Brenes and Roura, 2010).

The sensory evaluation results were similar to study reported by Katiyar et al. (1996) who indicated no significant differences $(p>0.05)$ in the qualitative and quantitative characteristics of the meat of chickens fed a diet containing $20 \%$ neem kernel cake. The sensory quality of breast and thighs was not affected by the addition of pumpkin seed of $1 \mathrm{~kg}$ on $100 \mathrm{~kg}$ of feed and also similar result was obtained by Wafar et al. (2017) inclusion of pumpkin seed meal up to $20 \%$ on the broiler chicken feed. Generally, the present findings show that addition of neem seed powder and pumpkin seed powder did not affect the juiciness, tenderness, flavor, and overall acceptance of the meat from the breast and thigh of broiler chicken and the meat were acceptable for the human consumption.

Significant difference in CP content of meat clearly showed that blood protein content is directly related to the muscle protein content. Similar results have been reported by Ihsan (2017) and these authors indicated addition of neem powder in broiler diets significantly $(p<0.05)$ higher crude protein value of the meat. The Moisture, Ether extract and Ash content of the breast and thigh meat of the broiler was not affected by the treatments. The chemical compositions of breast and thigh muscles recorded in the present experiment are within the range reported for broiler meat (Abdullah et al., 2010).

\section{Conclusion}

Based on results of the study neem and pumpkin seed has health improvement potential as a feed additive in broiler chicken ration without compromising meat sensory quality. The study results suggest that the addition of neem and pumpkin seed combination (0.5kg NS and $0.5 \mathrm{~kg}$ PS) on $100 \mathrm{~kg}$ broiler diets could be regarded as natural feed additives and environment safe and sound diets as alternatives to banned and hazardous synthetic antibiotics. 


\section{Acknowledgements}

The authors are grateful to Haramaya University Research and Extension Affairs Office for funding the work.

\section{Competing interests}

The authors declare that they have no competing interests.

\section{References}

Abdullah, Y.A., Al-Beitawi, N.A., Rjoup, M.M.S., Qudsieh, R.I. and Ishmais, M.A.A. 2010. Growth performance, carcass and meat quality characteristics of different commercial crosses of broiler strains of chicken. Poult. Sci., 47, 13-21.

Acorda, J.A., Emille, I.Y., Mangubat, C. and Divina, B.P. 2019. Evaluation of the in vivo efficacy of pumpkin (Cucurbita pepo) seeds against gastrointestinal helminthes of chickens. Turk. J. Vet. Anim. Sci., 43, 206-211.

Ahsan, U.H., Meraj, K.A. and Rasool, S., 1999. Effect of supplementing Allium sativum (garlic) and Azadirachta indica (neem) leaves in broilers feed on their blood cholesterol, triglycerides and antibody titer. Int. J. Agric. Biol., 1, 125-127.

Alcicek, A., Bozkurt, M., and Çabuk, M., 2003. The effect of essential oil combination derived from selected herbs growing wild in Turkey on broiler performance. S. Afr. J. Anim. Sci., 33, 89- 94.

Ani, A.O. and Okeke, G.C. 2011. The performance of broiler birds fed varying levels of roasted pigeon pea (Cajanus cajan) seed meal. Pak. J. Nutr., 10(11), 1036-1040.

AOAC, (Association of Official Analytical Chemists), 1995.Official Methods of Analysis of AOAC International, $16^{\text {th }}$ Edition. Virginia. USA.

Banerjee, S.B. 2006. Effect of probiotics on broiler production. Int. J. Poult. Sci., 5(6), 593-597.

Bauri, R.K., Mary, N.T., and Singray, S.K., 2015. Medicinal plant to control parasites. Indian J. Nat. Prod. Resour., 6, 268-277.

Bernard, F.F., Joseph, G.Z. and Jain, N.C. 2000. Schalm's Veterinary Hematology, $5^{\text {th }}$ edition. Lippincott williems and wilkins, Philadelphia.

Bonsu, F.R.K., Kagya-Agyemang, J.K., Kwenin, W.K.J. and Zanu, H.K. 2012. Medicinal response of broiler chickens to diets containing neem (Azadirachta indica) leaf meal, hematology and meat sensory analysis. World Appl. Sci. J., 19, 800-805. 
Brenes, A. and Roura, E. 2010. Essential oils in poultry nutrition: Main effects and modes of action. Anim. Feed Sci. Technol., 158, 1-14.

Douglas, J., Weiss, K., and Wardro, P.J., 2010. Veterinary Hematology, $6^{\text {th }}$ edition, Blackwell Publishing Ltd.

Doumas, B.T., Bayso, D.D., Carter, R.J., Peters, T. and Schaffer, R. 1981. Determination of total serum protein. Clin. Chem., 27, 1642-1643.

Fajinmi A.D., Adedeji, S.K., Hssan, W.A. and Babatunde, G.M., 1990. Inclusion of nonconventional feed stuff in rabbit concentrate ration. A case study on neem. J. Appl. Rabbit Res., 13, 125-128.

Fruhwirth, G. and Hermetter, A., 2007. Seeds and oil of the Styrian oil pumpkin components and biological activities. Eur. J. Lipid Sci. Tech., 109, 1128-1140.

Ihsan, M.S., 2017. Impact of supplementation Neem powder (Azadirachta indica) to diet broiler in immunological, physiological and productive traits. Adv. Environ. Biol., 11(3), 44-51.

Imran, A., Shahzad, A.K., Abid, H., Naveed, S., Gulzar, A. and Kashif, A., 2014. Effect of supplementation of ration with neem seed cake on the growth of broilers. Glob. Vet., 13(3), 414-418.

ISO, 2003. (International Standards Organization). ISO 13299. General Guidance for Establishing a Sensory Profile. ISO, Geneva, Switzerland.

Jawad, Z., Younus, M., Rehman, M.U., Maqbool, A., Munir, R., Muhammad, K., Korejo, R.A. and Qazi, I.H., 2013. Effect of Neem leaves (Azadirachta indica) on immunity of commercial broilers against new castle disease and infectious bursal disease. Afr. J. Agric. Res., 8, 4596-4603.

Katiyar, R.C., Verma, S.V.S., Nagalakshmi, D., Sastry, D.K. and Agrawal, R.C., 1996. Performance of broiler chicks fed on alkali treated neem kernel (Azadirachta indica) as protein supplement. Br. Poult. Sci., 37, 809-818.

Kerise, A., Maxine, D., Teran, C., Gardner, M., and Simon, O., 2008. Influence of pumpkin seed oil supplementation on cardiovascular and histological outcomes in female non-ovariectomized and ovariectomized Rats. FASEB Journal., 22, 719.

Meineri, G., Longato, E., and Peiretti, P.G., 2018. Effects of diets containing linseed oil or lard and supplemented with pumpkin seeds on oxidative status, blood serum metabolites, growth performance, and meat quality of naked neck chickens. Can. J. Anim. Sci., 98, 607-618. 
Mishra, B.B., Kidan, H.G., Kibret, K., Hassen, M. and Eshetu, B. 2004. Soil and land resource inventory at Haramaya University research farm with reference to land evaluation for sustainable agricultural management and production. Synthesis of working papers, Soil Science. Bulletin No. 1, 123p. Alemaya University, Dire Dawa, Ethiopia.

Ng, T.B., Parkash, A., and Tso, W.W., 2002. Purification and characterization of moschins, arginine-glutamate-rich proteins with translation inhibiting activity from brown pumpkin (Cucurbita moschata) seeds. Protein Expr. Purif., 26, 9-13.

Ogbuemu, I.P., Esonu, B.O. and Iloeje, M.U., 2011. The growing importance of neem in Agriculture, Industry, Medicine and Environment. J. Med. Plants Res., 5(3), 230-245.

Perez-Gutierrez, R.M. 2016. Review of Cucurbita pepo (Pumpkin) its phytochemistry and pharmacology. Int. J. Med. Chem., 6, 12-21.

SAS, 2002. SAS User's Guide. Statistics. SAS Institute, Inc., Cary, NC. USA.

Sirelkhatim B.E and Asha M.E. 2014. A review on Omega-6 essential fatty acids: Uses, benefits and their availability in pumpkins (Cucurbia maxima) seed and desert dates (Balanties aegyptiaca) seed kernel oils. Pak. J. Biol. Sci., 17, 1195-1208.

Wafar, R.J., Hannison, M.I., Abdullahi, U., and Makinta, A., 2017. Effect of Pumpkin (Cucurbita pepo L.) Seed Meal on the Performance and Carcass Characteristics of Broiler Chickens. Asian J. Adv. Agric. Res., 2(3), 1-7.

Windisch, W., Schedle, K., Plitzner, C., and Kroismayr, A., 2008. Use of phytogenic products as feed additives for swine and poultry. J. Anim. Sci., 86 (1), 140-148.

Xiong, X.M., 2000. Study on extraction and separation of effective composition of pumpkin polysaccharide and its glucatonic effect. Clin. Trad. Patent Med., 2, 563-565.

Yadav, M., Jain, S., Tomar, R., Prasad, K.S. and Yadav, H. 2000. Medicinal and biological potential of pumpkin: An updated review. Nutr. Res. Rev., 23, 184-190. 